\title{
ANALISIS KEBUTUHAN DAN PERILAKU PENCARIAN INFORMASI MAHASISWA DIFABEL UIN SUNAN KALIJAGA YOGYAKARTA
}

\author{
Hadira Latiar \\ Universitas Lancang Kuning, Pekanbaru, Riau, Indonesia \\ hadiralatiar6@gmail.com
}

\begin{abstract}
The need for information can happen to anyone, anytime, and anywhere. Therefore, the information needs will be very possible for students with disabilities. This study aims to see how the needs and behavior of students with disabilities in information search. The method that used in this research is qualitative method by observation and interview as data acquisition technique. Informants in this study are students with disabilities in UIN Sunan Kalijaga Yogyakarta, which are two people. The results of the research will be used as a basis, especially for library managers in the provision of library materials. Based on the above analisys results, it can be concluded that basically students with disabilities have the same needs and behavior with other students. Researchers identify the information required by students with disabilities, are: 1) lifestyle, 2) lectures, 3) general, 4) social life, 5) health and 6) future plans. While in the search for information, they tend to meet the information needs using the internet.
\end{abstract}

Keywords: Information Needs, Information Seeker Behavior, Disabilities. 


\begin{abstract}
Abstrak
Kebutuhan informasi dapat terjadi pada siapa saja, kapan saja, dan dimana saja. Oleh sebab itu kebutuhan informasi akan sangat mungkin terjadi pada mahasiswa difabel.Penelitian ini bertujuan untuk mengungkap bagaimana kebutuhan dan perilaku mahasiswa difabel dalam pencarian informasi. Metode yang digunakan dalam penelitian ini adalah metode kualitatif dengan melakukan observasi dan wawancara sebagai teknik perolehan datanya. Informan dalam penelitian ini adalah mahasiswa penyandang disabilitas UIN Sunan Kalijaga Yogyakarta, yaitu dua orang. Hasil penelitian nantinya dapat dijadikan sebagai dasar, terutama bagi pengelola perpustakaan dalam penyediaan bahan pustaka. Berdasarkan hasil analisa dapat disimpulkan bahwa pada dasarnya mahasiswa difabel memiliki kebutuhan dan perilaku yang sama dengan mahasiswa lainnya. Peneliti mengidentifikasi informasi yang dibutuhkan oleh mahasiswa difabel, adalah: 1) gaya hidup (lifestyle), 2) perkuliahan, 3) umum, 4) kehidupan sosial, 5) kesehatan dan 6) rencana masa depan. Sedangkan dalam pencarian informasi, mereka cenderung memenuhi kebutuhan informasinya menggunakan internet.
\end{abstract}

Kata Kunci: Kebutuhan informasi, Perilaku Pencari Informasi, Difabel.

\title{
A. Pendahuluan
}

Kebutuhan informasi setiap manusia tidak terbatas, dikarenakan manusia adalah manusia yang ingin selalu berkembang. Dalam konteks ilmu informasi, kebutuhan informasi muncul ketika sesorang menyadari bahwa mereka tidak memiliki atau kekurangan pengetahuan atau pemahaman untuk mencapai tujuan, menjawab pertanyaan dan lain sebagainya. ${ }^{1}$ Kebutuhan informasi timbuldisebabkan karena kesenjangan pengetahuan

${ }^{1}$ Sue Batley, Information Architecture for Information Profesionals (England: Chandos Publishing, 2007), 19. 
seseorang, maka orang tersebutakan berusaha memenuhi kebutuhan informasinya agar segera terpenuhi.

Wilson menyatakan bahwa munculnya kebutuhan manusia dikategorikan menjadi tiga yaitu; kebutuhan fisiologis, kebutuhan afektif, dan kebutuhan kognitif.Sewaktu seseorang terdorong untuk mencari informasi semua faktor fisiologis, afektif maupun kognitif akan menentukan bagaimana seseorang berperilaku mencari informasi. Selain itu ada juga faktor rintangan yang akan menentukan bagaimana akhirnya seseorang bertindak tanduk dalam lingkungan sebuah sistem informasi. ${ }^{2}$

Kebutuhan informasi akandirasakan terus bertambah bagi sesorang jika setiap kali ia memiliki rasa ingin tahu yang tinggi terhadap sesuatu dan memiliki tujuan yang ingin dicapai. Tidak ada seorang pun yang tidak membutuhkan informasi, apa pun jenis pekerjaan orang itu. Kebutuhan informasi dapat terjadi pada siapa saja, kapan saja, dan dimana saja. Jadi kebutuhan informasi akan sangat mungkin terjadi pada mahasiswa difabel.

Harus disadari bahwa keterbatasan secara fisik atau mental seorang difabel tidaklah menghapus hak-hak mereka sebagai warga negara, termasuk pula hak untuk mengakses informasi. ${ }^{3}$

Difabel memiliki kebutuhan khusus dalam menjalani kehidupan sehari-hari, tak terkecuali dalam mengakses informasi. Informasi yang kini menjadi suatu kebutuhan juga diperlukan oleh difabel terutama bagi mereka yang sedang mengenyam pendidikan. Namun, lagi-lagi kesenjangan akses informasi menjadi suatu isu sentral dalam ketidak-berdayaan difabel dan hal ini diperparah dengan fakta bahwa diskriminasi akan akses informasi bahkan terjadi dalam institusi pendidikan. ${ }^{4}$

${ }^{2}$ T. D. Wilson, "On user studies and information needs," Journal of Documentation Vol. 37, No.1 (1981): 9.

${ }^{3}$ Ari Zutriana, "Hak Informasi Bagi Difabel," Jurnal Pustakaloka Vol.3, No. 2 (2011): 20.

${ }^{4}$ Nadia Wasta Utami, “Gelap dalam Gemerlap Gelapnya Akses Informasi Bagi Difabel dalam Gemerlap Era Digitalisai," Jurnal Chanel Vol. 3, No.2 (2015): 45. 
Penulis menganggap penelitian ini sangat penting, karena penelitian mengenai kebutuhan dan perilaku mahasiswa difabel dalam pencarian informasi masih belum banyak dilakukan. Selama ini, penelitian mengenai kebutuhan dan perilaku pencarian informasi lebih banyak diterapkan untuk kalangan mahasiswa yang tidak berkebutuhan khusus.Selain itu, penelitian ini penting untuk dilakukan guna mengidentifikasi kondisi nyata terkait kebutuhan dan perilaku mahasiswa difabel.

Berdasarkan uraian latar belakang tersebut, yang menjadi rumusan masalah dalam penelitian ini adalah:

1. Bagaimana kebutuhan informasi mahasiswa difabel di UIN Sunan Kalijaga Yogyakarta?

2. Bagaimana perilaku pencarian informasi mahasiswa difabel di UIN Sunan Kalijaga Yogyakarta?

Dengan demikian tujuan penting yang diperoleh dari hasil penelitian ini adalah:

1. Mengidentifikasi kondisi nyata mengenai kebutuhan dan perilaku mahasiswa difabel dalam pencarian informasi.

2. Memberikan gambaran mengenai kebutuhan dan perilaku mahasiswa difabel dalam pencarian informasi tersebut di atas dapat dijadikan sebagai dasar dalam penyediaan bahan pustaka.

3. Serta memberikan masukan dan rekomendasi bagi pihak terkait tentang kebutuhan koleksi perpustakaan UIN Sunan Kalijaga.

\section{Metode Penelitian}

Dalam penelitian ini, penulis menggunakan pedekatan kualitiatif dengan metode studi kasus. Guna memperoleh data dalam penelitian ini, penulis menggunakan beberapa teknik pengambilan data yakni observasi, wawancara mendalam, dan analisis dokumen. Subjek dalam penelitian ini adalah kebutuhan dan perilaku pencarian informasi mahasiswa difabel UIN Sunan 
Kalijaga. Penentuan sampel penelitian, penulis menggunakan teknik sampel bertujuan (purposive sample) yaitu dengan mengambil sampel yang benar-benar merupakan subjek paling banyak mengandung ciri-ciri yang terdapat pada populasi.Adapun karakteristik penentuan sampel yaitu mahasiswa aktif UIN Sunan Kalijaga yang memyandang disabilitas dari semua program studi, sampel bersedia dijadikan informan, dan informan sering memanfaatkan perpustakaan UIN Sunan Kalijaga.Maka diperoleh informan dalam penelitian ini adalah mahasiswa difabel UIN Sunan Kalijaga Yogyakarta, berjumlah dua mahasiswa.Data penelitian direkam dan dicatat menggunakan teknik pengamatan langsung dan wawancara mendalam tak terstruktur.Dengan menggunakan pengumpulan data tersebut, peneliti dapat mengeksplorasi interpretasi-interpretasi yang berbeda-beda dari masing-masing informan.Data-data yang dikumpulkan berupa catatan-catatan dan rekaman suara dalam format Mp3 yang diperoleh selama observasi dan wawancara.

Dalam menganalisis dan menginterpretasikan data, peneliti menggunakan tiga tahapan dalam analisis data yaitu; reduksi data, penyajian data, dan penarikan kesimpulan/ verifikasi. Ketiga komponen dilakukan bersamaan dengan proses pengumpulan data. Setelah data terkumpul, maka tiga komponen tersebut berinteraksi.

\section{B. Pembahasan}

\section{Hasil Penelitian}

Sebelum sampai pada analisis data, terlebih dahulu peneliti akan memperkenalkan profil informan agar dapat diketahui sekilas tentang latar belakang informan yang menjadi narasumber dalam penelitian ini. Dua mahasiswa difabel telah menjadi informan dalam penelitian ini. Berdasarkan etika penulisan penelitian maka dalam penelitian ini, peneliti menggunakan nama samaran untuk mengidentifikasi masing-masing informan. Dalam penelitian ini penulis hanya fokus mengambil dua informan difabel dengan 
keterbatasan dalam pengelihatan atau sering disebut tuna nerta. Berikut ini adalah gambaran profil kedua informan tersebut dan urutan penyebutan informan di bawah ini sesuai dengan urutan wawancara.

Informan pertama adalah Putri seorang mahasiswa berusia 21 tahun. Putri adalah seorang mahasiswa semester 5 pada jurusan Bahasa Arab UIN Sunan Kalijaga Yogyakarta. Putri merupakan seorang difabel dengan keterbatasan dalam pengelihatan atau sering disebut tuna netra. Keterbatasannya ini ia alami sejak lahir. Meskipun memiliki keterbatasan dalam pengelihatan, ia tidak putus asa dalam menjalani hidup. Atas semangat belajar, dukungan orang tau dan keluarga akhirnya dia berhasil menempuh pendidikan hingga perguruan tinggi. Putri yang memiliki kegemaran dalam membaca dan menulis ini bahkan mempunyai cita-cita ingin menjadi guru.

Informan kedua adalah Putra seorang mahasiswa berusia 25 tahun. Putra berasal dari Magelang. Putra adalah seorang mahasiswa semester 7 pada jurusan manajemen dakwah UIN Sunan Kalijaga Yogyakarta. Putra merupakan seorang difabel dengan keterbatasan dalam pengelihatan atau tuna netra sama dengan informan pertama. Putra sangat senang bisa berkuliah di UIN Sunan Kalijaga Yogyakarta. Ia berharap setelah lulus kuliah dapat membagikan ilmu yang dimiliki kepadabanyak orang.

\section{Pembahasan}

Seluruh informan baik Putri maupun Putra sepakat bahwa mereka sebagai mahasiswa difabel membutuhkan informasi. Pertanyaan mendasar yang yang diajukan kepada informan yaitu mengenai pemahaman mereka tentang kebutuhan informasi. Berdasarkan wawancara yang dilakukan, ada informan sedikit kesulitan untuk mengungkapkan apa yang mereka ketahui tentang kebutuhan informasi. Informan Putri memiliki persepsi dan pemahaman bahwa informasi hanya sebatas pada berita atau pengetahuan, seperti yang diungkapkan berikut: 
"Butuh, informasi itu sesuatu seperti berita dan pengetahuan. Biasanya kalau orang yang sering membaca berita jadi banyak mengetahui dunia luar dan akan banyak pengetahuan gitu" (Putri)

Putri mengakui bahwa dirinya membutuhkan informasi tetapi Putri tidak membedakan antara informasi dan pengetahuan. Padalah informasi dan pengetahuan itu berbeda. Informasi sering disamakan atau disinonimkan dengan data dan pengetahuan, padahal ketiganya adalah hirarki, dengan data dibagian bawah dan pengetahuan dibagian atas.Informasi adalah data yang diproses dan dikelola, sedangkan pengethauan adalah informasi yang telah disaring, dikelola, dan dipahami oleh otak manusia. Informasi diperoleh dengan cara diminta, sedangkan pengetahuan dapat diperoleh dalm pikiran dan informasi maupun menghasilkan pengetahuan. ${ }^{5}$ Putri menganggap informasi seperti berita dan pengetahuan, dan menurutnya dengan membaca berita di koran maupun menonton berita di TV dapat menambah pengetahuannya. Definisi tentang informasi yang diungkapkan Putri hampir sama dengan yang dikemukakan oleh Putra, bahwa informasi adalah fakta, data, kepercayaan, pendapat dan pengetahuan yang tersimpan, antara lain adalah monograf, jurnal, bahan pandang dengar atau bahkan dalam pikiran manusia.

Informan Putra menganggap bahwa informasi dapat diakses dengan menggunakan media, seperti yang diungkapkan berikut:

"Buruh banget mas... Seperti informasi tentang berita yang lagi panas-panasnya, misalnya berita politik gitu... Informasi itu ya suatu media untuk membuat kita menjadi lebih tahu segala hal. Jadi yang tadinya ndak tau jadi tau..."

Informan Putra menganggap bahwa informasi adalah sesuatu untuk mengurangi ketidakpastian, dimana yang sebelumnya

${ }^{5}$ Donald O. Case, Looking for Information: A Survey of research in information seeking, needs, and behavior (2nd ed) (California: Academic Press, 2007), 64 . 
tidak tahu kemudian karena mendapatkan informasi menjadi tahu. Dengan ketidakpastian atau kesenjangan informasi dalam dirinya memunculkan timbulnya kebutuhan infromasi.Selain itu informan Putra juga menganggap informasi seperti berita.

\section{a. Kebutuhan Informasi Mahasiswa Difabel UIN Sunan Kalijaga}

Informasi yang dibutuhkan mahasiswa difabel dalam penelitian ini dikategorikan berdasarkan temuan penulis di lapangan. Penulis mengidentifikasi informasi yang dibutuhkan oleh mahasiswa difabeladalah:1) gaya hidup (lifestyle), 2) perkuliahan, 3) umum, 4) kehidupan sosial, 5) kesehatan dan 6) rencana dimasa depan.

\section{1) Gaya hidup(Lifestyle)}

Gaya hidup (Bahasa Inggris: lifestyle) adalah bagian dari kebutuhan sekunder manusia yang bisa berubah bergantung zaman atau keinginan seseorang untuk mengubah gaya hidupnya. ${ }^{6}$ Gaya hidup dapat dikatakan seperti pola hidup sesorang dalam berinteraksi dengan lingkungan dan orang disekitarnya yang diekspresikan. Putri membutuhkan informasi yang berkaitan dengan hobi, seperti yang diungkapkan berikut:

"Informasi-informasi yang menyangkut sama hobi gitu mas...Karena hobi saya membaca dan menulis jadi saya butuh informasi tentang buku-buku bacaan dan informasi lain untuk menunjang hobi saya..." (Putri)

Putri membutuhkan informasi yang berhubungan dengan hobinya untuk menunjang hobinya. Gaya hidup dapat dilihat juga dari cara orang mengisi waktu senggangnya. Seperti yang diungkapkan informan Putra berikut:

"Paling denger musik di hape, lagu-lagu kesukaan gitu sih mas untuk mengisi waktu luang" (Putra)

6 "Gaya Hidup," Wikipedia (blog), diakses 1 November 2017, https:// id.wikipedia.org/wiki/Gaya_hidup. 
Putra mengungkapkan bahwa dirinya mengisi waktu senggangnya dengan mendengarkan musik.Biasanya dia menggunakan Gadgetmiliknya untuk hiburan dengan mendengarkan musik. Hiburan merupakan sebuah kebutuhan untuk melepaskan diri dari ketegangan emosional atau kebutuhan untuk melarikan diri dan hasrat untuk mencari pengalihan. ${ }^{7}$ Dapat dipahami bahwa kedua mahasiswa difabel mempunyai gaya hidup yang berbeda, khususnya terkait dengan hobi. Maka untuk memenuhi kebutuhan informasi terkait hobi pun berbeda, informan pertama memenuhi kebutuhan informasi terkait hobi dengan cara membaca buku dan mencari informasi yang menunjang hobinya. Sedangkan informan kedua memenuhi informasi terkait gaya hidup dengan cara mendengarkan lagu-lagu kesukaan. Hal ini tidak bisa dipungkiri bahwa perkembangan teknologi informasi sangat mempengaruhi cara memenuhi kebutuhan informasi terkait gaya hidup mahasiswa difabel.

2) Perkuliahan

Kebutuhan yang berhubungan dengan kuliah dan mata kuliah mencakup kebutuhan informasi yang berhubungan dengan akademik dan tugas mata kuliah.Informasi yang dibutuhkan informan menyangkut perannya sebagai mahasiswa yaitu menyelesaikan tugas dan menghadapi ujian. Informan Putri mengungkapkan bahwa dirinya membutuhkan informasi untuk menyelesaikan tugas kuliah, seperti yang dungkapkan berikut:

“...kaya' ini mau presentasi, selain mempersiapkan tugasnya biasanya cari dulu bahan-bahan biar nanti kalau ada pertanyaan dari dosen atau temen-temen bisa jawab" (Putri)

Putri membutuhkan informasi yang berkaitan dengan tugas kuliah untuk mempersiapkan menghadapi presentasi.

${ }^{7}$ Pawit M Yusup, Pedoman Mencari sumber Informasi. (Bandung: Remaja Rosdakarya, 1998), 12. 
Dengan harapan apabila ada pertanyaan dari dosen dan teman sekelasnya ia bisa menjawab. Selain Putri, Putra juga membutuhkan informasi untuk menyelesaikan tugas kuliahnya, seperti yang diungkapkan berikut:

"Kalo sekarang lagi sibuk cari informasi dan tanya bahan-bahan sama temen untuk buat tugas mas..." (Putra)

Tugas kuliah adalah tugas yang diberikan dari dosen pengampu mata kuliah kepada mahasiswanya, agar mahasiswa bisa belajar mandiri selain di ruang kelas. Karena setiap dosen pasti memberikan tugas kepada mahasiswa, Putra mencari bahan dan bertanya informasi tentang tugas kepada teman-temannya supaya tugasnya dapat diselesaikan. Kedua informan sama-sama membutuhkan informasi yang berhubungan dengan perkuliahan, khususnya untuk menyelesaikan tugas yang diberikan oleh dosen. Informasi yang dibutuhkan oleh mereka diperoleh dari berbagai sumber, khususnya dari internet. Hal ini menunjukkan bahwa mereka merupakan mahasiwa yang sangat memperhatikan tugas-tugas yang diberikan oleh dosen, dan berusaha untuk menyelesaikan tugas-tugas tersebut dengan baik.

\section{3) Umum}

Informasi umum mencakup peristiwa terkini, politik, agama, dan masalah sosial.Peristiwa terkini yaitu kejadian yang terjadi pada saat ini. Putri membutuhkan informasi umum seputar cuaca karena kondisi cuaca yang saat ini tidak menentu, seperti yang diungkapkan berikut:

"Informasi tentang cuaca, kan kalau hujan kita ada persiapan untuk bawa payung...” (Putri)

Putri juga membutuhkan informasi seputar perkiraan cuaca. Cuaca yang tidak menentu dan sulit diprediksi (yaitu kadang panas sekali namun tiba-tiba hujan) membuat Putri membutuhkan informasi tersebut. Cuaca adalah keadaan 
udara baik temperaturnya, cahaya matahari, kelembapan udara, kecepatan angin pada suatu tempat tertentu. Putri biasa mendapatkan informasi tersebut dari internet yaitu perkiraan cuaca.

Berbeda dengan Putri, Putra mengungkapkan bahwa dirinya membutuhkan informasi menyangkut berita terkini, seperti yang diungkapkan berikut:

"Kayak sekarang ini kan lagi banyak membicarakan tentang informasi hoax.... Paling suka dengar cerita dari temen-temen mas..." (Putra)

Informasi mengenai berita terkini yang sedang ramai diperbincangkan juga menarik perhatian Putra.Ini sesuai dengan definisi informasi yang Putra berikan bahwa informasi seperti berita. Berita merupakan keterangan mengenai peristiwa atau kejadian. Dari uraian tersebut disimpulkan bahwa kedua informan selalu memperbarui pengetahuan mereka dengan mengikuti perkembangan terbaru yang sedang populer di internet, seperti fenomena hoax, mengenai cuaca dan berita-berita terkini. Mereka mendapatkan informasi dari berbagai sumber, seperti temanteman, dan internet untuk memenuhi kebutuhan.

\section{4) Kehidupan Sosial}

Mahasiswa membutuhkan informasi untuk menunjang kehidupan sosial seperti berhubungan dengan orang lain mencakup keluarga, teman, rekan atau kenalan lainnya. Putri membutuhkan informasi tentang orang-orang disekitarnya untuk menunjang kehidupan sosialnya dengan cara bersosialisasi. Informasi tentang cara bersosialisasi dibutuhkan agar Putri dapat diterima oleh orang-orang di lingkungannya, seperti yang diungkapkan berikut:

“...Pengetahuan tentang cara bersosialisasi. Kalo kita nggak tau cara bersosialisasi nanti jadi kuper (kurang pergaulan), nggak punya temen, dan bertemen sama itu- 
itu aja. Hehehehe... Ya... misalnya kita pergi ke tempat baru jadi kita harus tau tentang lingkungan sekitar agar dapat menyesuaikan diri di lingkungan..." (Putri)

Pada saat berhubungan dengan orang-orang disekitarnya Putri berusaha untuk mengenal dan menyesuaikan diri dengan lingkungannya. Putri mengungkapkan bahwa cara bersosialisasi dapat dilakukan dengan cara belajar beradaptasi dengan kondisi, memperluas wawasan, menyambung silahturahmi. Lingkungan terkadang juga mempengaruhi kebutuhan informasi seseorang, dan informasi juga dapat mempengaruhi lingkungan seseorang.

Sedangkan informan Putra mendapatkan informasi dari temannya seputar teman lainnya, seperti diungkapkan berikut:

"Informasi taunya dari temen aja, biasanya kayak ada temen yang sakit ya tanya-tanya aja. Biasanya sih dikasih tau sama temen" (Putra)

Putra memperoleh informasi tentang temannya dari teman yang lainnya. Apa yang dilakukan Putra tersebut senda dengan yang dikatakan oleh Agustus dan HughesHassell bahwa teman dan anggota keluarga adalah sumber yang lebih disukai remaja. Semua informan membutuhkan informasi untuk menunjang kehidupan sosial dalam berhubungan dengan orang lain mencakup teman, rekan, atau kenalan lainnya. Pada saat memenuhi informasi, informan berhubungan dengan orang-orang disekitarnya. Meskipun kedua informan memiliki keterbatasan, mereka selalu berusaha untuk menyesuaikan diri dengan lingkungan sekitar, dan peduli terhadap teman yang sedang mengalami musibah.

5) Kesehatan

Kesehatan berhubungan dengan kesehatan jasmani, kecantikan, alkohol,/narkoba, seks dan lain sebagainya. 
Informan Putri beranggapan bahwa ia butuh informasi tentang kesehatan secara menyeluruh, dan menanyakan informasi seputar kesehatan kepada dokter atau keluarga, seperti yang diungkapkan berikut:

“....butuh seluruh informasi tentang kesehatan, ya apa aja yang menyangkut kesehatan.... Biasanya tanya sama dokter dan sama keluarga..." (Putri)

Karena Putri menyadari punya keterbatasan dalam pengelihatan, jadi ia sangat membutuhkan informasi seputar kesehatan untuk mengetahui kondisi kesehatannya. Informan Putra juga membutuhkan informasi tentang kesehatan berdasarkan pengelamannya selama ini yang sakit perut. Selain itu Putra juga membutuhkan informasi seputar kesehatan lainnya, seperti diungkapkan berikut:

“...Iya kayak waktu itu pernah cari makanan apa yang baik dan nggak baik terus yang mengandung apa, pokoknya seputar makanan gitu. Tanya sama teman aja mas..." (Putra)

Putra membutuhkan informasi seputar pemahaman kesehatan umum seperti makanan yang baik untuk kesehatan. Putra mendapatkan informasi tentang kesehatan dari temantemannya. Kesehatan menjadi perhatian khusus bagi kedua informan, mereka selalu membutuhkan informasi kesehatan untuk menjaga kesehatan dengan cara menanyakan kepada dokter, keluarga dan teman terdekat. Hal ini dikarenakan keterbatasn mereka, khususnya mahasiswa yang memiliki keterbatasan dalam pengelihatan, dengan menanyakan seputar makanan yang baik.

6) Rencana Masa Depan

Rencana masa depan yang dimaksud di sini mencakup capaian dalam kuliah, karir dan lain sebagainya. Karena Putri sekarang sudah semester 5 maka Putri membutuhkan 
informasi tentang karirnya setelah lulus dari kuliah, seperti yang diungkapkan berikut:

“....biasanya saya cari informasi lowongan guru, karena cita-cita saya itu guru.... " (Putri)

Putri membutuhkan informasi untuk merencankan masa depannya seperti iformasi tentang lowongan kerja guru. Ia mendapatkan informasi lonwogan pekerjaan dari internet dan dosen. Berbeda dengan informan Putra yang sudah merencanakan ingin melanjutkan kuliah S2 (Pascasarjana), seperti yang diungkapkan berikut:

“...rencananya sih pengen lanjut S2, jadi cari info tentang S2 aja..." (Putra)

Putra merencanakan untuk lanjut kuliah pascasarjana. Karena ingin lanjut kuliah jadi Putra hanya mencari informasi tentang program pascarjana yang akan dipilihnya. Berdasarkan hasil pembahasan di atas, dapat disimpulkan bahwa meskipun mereka memiliki keterbatasan tetapi mereka tidak putus asa dan memiliki cita-cita yang sama dengan mahasiswa lainnya. Mereka menyadari bahwa mereka memiliki hak yang sama, sehingga apa yang menjadi rencana masa depan harus selalu diraih. Kedua informan selalu berupaya untuk memenuhi kebutuhan informasi terkait informasi terkait cita-cita atau rencana di masa depan.

\section{b. Perilaku Mahasiswa Difabeldalam Pencarian Informasi}

Setiap orang memiliki perilaku dan karakteristik tertentu dalam memenuhi kebutuhan informasinya.Menurut Wilson bahwa guna memenuhi kebutuhan informasinya, setiap orang harus memiliki pengetahuan yang saling berkaitan. ${ }^{8}$ Untuk mendapatkan informasi tersebut, seorang mahasiswa difabel harus terlibat dalam proses pencarian informasi yang nantinya akan memunculkan perilaku dalam pencarian informasi.

\footnotetext{
${ }^{8}$ Wilson, "On user studies and information needs."
} 
Setelah informan merasakan bahwa dirinya membutuhkan informasi, maka selanjutnya ia akan berusaha mencari informasi yang diinginkannya pada sumber-sumber informasi yang tersedia dan diketahuinya. Dalam proses pemenuhan kebutuhan informasi informan memerlukan sumber informasi. Semua informan mengungkapkan bahwa mereka cenderung memenuhi kebutuhan informasinya menggunakan internet, seperti yang diungkapkan berikut:

"Untuk bahan-bahan tugas kuliah biasanya cari di internet sama perpustakaan, untuk informasi yang lain lebih suka pake internet. ... kalo di perpus kan nggak semua bisa dipinjam..." (Putri)

Putri menggungkapkan bahwa dirinya lebih suka mencari informasi di internet. Kepraktisan dan daya tarik yang ditawarkan oleh internet membuat Putri lebih menyukai internet dibandingkan dengan koleksi perpustakaan. Informasi yang Putri peroleh dari internet seperti informasi tentang peristiwa atau berita terkini, hiburan, dan hubungan dengan orang lain. Sedangkan untuk mengerjakan tugas kuliah, Putri lebih memilih koleksi perpustakaan karena lebih lengkap tetapi tidak semua koleks perpustakaan bisa dipinjam.

Sama halnya dengan Putri, Informan Putra juga lebih memilih internet dibandingkan dengan buku. Seperi yang diungkapkan sebagai berikut:

"Lebih sering pakai internet, karna sekarang kan internet lebih canggih. Kami (difabel) juga bisa mengskses internet..internet lebih memudahkan..." (Putra)

Hal tersebut terjadi karena menurut mereka buku kurang menarik, karena sudah ada internet yang bisa digunakan dimanapun, kapanpun dan siapapun bisa mengaksesnya. Walaupun mereka lebih menyukai internet dalam pemenuhan informasi, tetapi mereka masih sering juga memanfaatkan orang lain, teman dan keluarga dalam pemenuhan kebutuhan informasi. 


\section{Simpulan dan Saran}

\section{Simpulan}

Berdasarkan hasil pembahasan dapat ditarik kesimpulan bahwa:

a. Kebutuhan informasi mahasiswa difabel pada umumnya samadengan kebutuhan mahasiswa lainnya. Terbukti dengan informasi yang dibutuhkan oleh mahasiswa difabel adalah informasi yang berkaitan dengan informasi umum, perkuliahan, informasi umum (peristiwa terkini), kehidupan sosial, kesehatan dan juga perencanaan masa depan. Kebutuhan informasi mahasiswa dipengaruhi oleh peran sosial yang dimiliki dan juga lingkungan sekitarnya. Tidak semua kebutuhan informasi mahasiswa difabel diekspresikan dan tidak disadari oleh mereka.

b. Sedangkan perilaku dalam memenuhi kebutuhan informasi, mahasiswa difabel lebih tertarik dan cenderung mencari informasi pada internet dari pada perpustakaan,hal ini karena kecanggihan dan kecepatan dalam mencari informasi yang diberikan oleh internet. Selain itu ada upaya dilakukan mahasiswa difabel dalam memenuhi kebutuhan informasi yaitudengan meminta bantuan kepadaorang lain seperti; teman, keluarga, dosen, dan orang disekitarnya.

\section{Saran}

Penulis menyarankan kepada seluruh mahasiswa difabel untuk lebih meningkatkan pemanfaatan perpustakaan UIN Sunan Kalijaga.Selain itu, pihak terkait dalam hal ini perpustakaan agar lebih memperhatikan kebutuhan informasi mahasiswa difabel, yaitu dengan menambah koleksi yang beragam, dan lebih aktif melakukan pendampingan terkait pencarian informasi. 


\section{DAFTAR PUSTAKA}

Batley, Sue. Information Architecture for Information Profesionals. England: Chandos Publishing, 2007.

Case, Donald O. Looking for Information: A Survey of research in information seeking, needs, and behavior (2nd ed). California: Academic Press, 2007.

“Gaya Hidup.” Wikipedia (blog). Diakses 1 November 2017. https:// id.wikipedia.org/wiki/Gaya_hidup.

Utami, Nadia Wasta. "Gelap dalam Gemerlap Gelapnya Akses Informasi Bagi Difabel dalam Gemerlap Era Digitalisai." Jurnal Chanel Vol. 3, No.2 (2015).

Wilson, T. D. “On user studies and information needs." Journal of Documentation Vol. 37, No.1 (1981).

Yusup, Pawit M. Pedoman Mencari sumber Informasi. Bandung: Remaja Rosdakarya, 1998.

Zutriana, Ari. "Hak Informasi Bagi Difabel." Jurnal Pustakaloka Vol.3, No. 2 (2011). 
